\title{
SODIUM, FAT, AND CHOLESTEROL CONTENTS IN EAST JAVA TRADITIONAL FOOD
}

\author{
Harun Al Rasyid \\ Department of Public Health, \\ Faculty of Medicine Universitas Brawijaya
}

\begin{abstract}
BACKGROUND: Restriction of sodium, total fat, saturated fat, cholesterol and trans-fats consumption are essential to control blood pressure. Health professionals in Indonesia such as doctor, nurse, and midwife, often have difficulty in providing advice related to traditional food consumption to prevent hypertension, due to the lack of information of nutrient contents in traditional food. This study aimed to identify and compare sodium, total fat, saturated fat, cholesterol and trans-contents in ten groups of traditional food in East Java

SUBJECT AND METHODS: This was an analytic observational study using cross-sectional design. Fifty samples of food were selected purposively from food vendors in Malang city, which were then divided into 10 groups. These groups of traditional food included rawon, chicken soto, beef soto, chicken satay, lamb satay, meatball, tahu lontong (tahu tek), rujak cingur, tahu campur, and pecel. Sodium content was measured using spectrophotometry. Total fat was measured using soxhlet method. Saturated fat, trans-fat, and cholesterol were measured using modified chromatography column. One-way ANOVA was used for data analysis.

RESULTS: Levels of sodium, total fat, saturated fat, cholesterol, and trans fats were significantly different among the 10 groups of traditional food ( $p<0.001)$. Tahu tek showed the highest (mean \pm SD) sodium level $(191.6 \pm 32.2 \mathrm{mg})$ and total fat $(33.7 \pm 2.2$ grams $)$ content per 100 grams of food. The highest cholesterol content was found in lamb satay (124.8 \pm 7.9 $\mathrm{mg}$ ) and rawon $(124 \pm 10.3 \mathrm{mg})$ per 100 grams of food. All food groups except pecel had high saturated fat content. All food groups contained low level of trans-fats.
\end{abstract}

CONCLUSION: People should be aware and advised to limit their consumption of tahu tek, lamb satay, and rawon.

Keywords: traditional food, sodium, fat, cholesterol, East Java 